\title{
Cukorbeteg gyermekek
} együttmüködésének vizsgálata a Diabetes Adherencia Kérdőív gyermekváltozatának validálása során

\author{
Munkácsi Brigitta - Nagy Beáta Erika dr. - Kovács Karolina Eszter dr. \\ Debreceni Egyetem, Általános Orvostudományi Kar, Gyermekgyógyászati Klinika, Debrecen
}

\begin{abstract}
Bevezetés: Az l-es típusú (ITDM) cukorbetegségben szenvedő serdülők többségének $\mathrm{HbA}_{1 c}$-értéke világszerte a céltartomány felett van. Annak ellenére, hogy már számos kutatás foglalkozott a diabetesspecifikus adherencia vizsgálatával gyermek- és serdülókorban, nem létezik rendszerszintû́ módszer, eljárás az öngondoskodás korlátainak azonosítására.

Célkitüzés: A kutatás célja egy olyan magyar nyelvú, megbízható és valid kérdőív létrehozása, amely magában foglalja az l-es típusú cukorbetegséggel kapcsolatos adherencia valamennyi területét.

Módszer: A jelen kutatásban a figyelem középpontjában a gyermek- és serdülőkorban egyaránt használható, diabetesspecifikus adherenciát vizsgáló új kérdőivüunk állt. A kérdốiv teszteléséhez, itemredukciójához és skáláinak meghatározásához megbízhatósági elemzést (Cronbach- $\alpha$ mutatót), illetve faktoranalízist alkalmaztunk.

Eredmények: Az eddigi angol nyelvú kérdőívek magyar nyelvre történő lefordítása, elótesztelése, majd a faktoranalízissel és megbízhatósági teszttel történt redukálása alapján létrehozott, 9 alskálát tartalmazó, 58 állításos új kérdőiv megbízhatónak bizonyult a Cronbach- $\alpha$ mutató alapján.

Következtetés: A létrehozott Diabetes Adherencia Kérdőiv (DAK) megbízhatóan alkalmazható gyermek- és serdülőpopuláción, s adaptálható más krónikus betegek számára is.
\end{abstract}

Orv Hetil. 2019; 160(29): 1136-1142.

Kulcsszavak: 1-es típusú cukorbetegség, adherencia, gyermek- és serdülókor

\section{Investigation of the adherence of children with diabetes through the validation of the child version of the Diabetes Adherence Questionnaire}

Introduction: Most of the adolescents suffering from type 1 diabetes mellitus (TlDM) can be described with $\mathrm{HbA}_{\mathrm{lc}}$ values below the target level. Several research investigated the impact of diabetes on the quality of life, however, no complex questionnaire has been developed to examine each area of the disease.

Aim: The aim of the present study is to create a Hungarian, reliable and valid questionnaire which can cover each aspect of the adherence related to type 1 diabetes mellitus.

Method: In the present study, the attention was drawn to the introduction of a new questionnaire related to diabetes adherence which can be applied among children and adolescents as well. To test the questionnaire and to reduce the number of the items and to determine the scales, reliability analysis (Cronbach's $\alpha$ ) and factor analysis was applied. Results: The new measurement, which was created through the translation of English language international questionnaires, their pre-test, and its reduction by factor and reliability analysis, containing 9 subscales with 58 items, is stated as reliable regarding the results of the Cronbach's $\alpha$ index.

Conclusion: It can be stated that the created Diabetes Adherence Questionnaire can be reliably applied on child and adolescent population and it can be adapted for people suffering from other types of chronic diseases.

Keywords: type 1 diabetes mellitus, adherence, childhood and adolescence

Munkácsi B, Nagy BE, Kovács KE. [Investigation of the adherence of children with diabetes through the validation of the child version of the Diabetes Adherence Questionnaire]. Orv Hetil. 2019; 160(29): 1136-1142. 


\section{Rövidítések}

DAF $=$ Diabetes Adherencia Felmérés $;$ DAK $=$ Diabetes Adherencia Kérdőív; $\mathrm{HbA}_{\mathrm{lc}}=$ hemoglobin $\mathrm{A}_{\mathrm{lc}}$ vagy glikohemoglobin; sd = standard deviáció

Világszerte a diabeteses fiatalok többségének $\mathrm{HbA}_{1 \mathrm{c}}$-értéke a referenciaövezettől eltérő tartományban van, amely tény sürgős beavatkozást tesz szükségessé a hatékony kezelési stratégiák, valamint a metabolikus status tartós javítása érdekében $[1,2]$. Népegészségügyi szempontból rendkívül fontos lenne a diabeteses adherencia, ezáltal a glükóz-, tágabb értelemben véve az ún. metabolikus kontroll javítása fiatalabb életkorban megvalósulhat. Orvosi gyakorlati tapasztalat, hogy a gyermekkori szuboptimális glikémiás kontroll fontos prediktora a felnőttkori szuboptimális glikémiás kontrollnak $[3,4]$.

$\mathrm{Az}$ adherencia az „egyén egészségügyi szakemberrel egyeztetett ajánlásoknak megfelelő viselkedése a gyógyszerszedés, a diéta és az életmódváltozás területén” [5]. „Az adherenciára irányuló beavatkozások hatékonyságának növelése nagyobb hatással lehet a népesség egészségére, mint az egyes gyógyszeres kezelések javítása" [5]. Fontos része a krónikus betegséggel való együttélésnek, és a terápia hatékonyságát is jelentős mértékben befolyásolja. Véleményünk szerint az adherenciára irányuló beavatkozások hatékonyságnövelésének kulcstényezője a diabetesszel való együttélést, az azzal való megküzdést befolyásoló pszichés tényezők pozitív irányba történő befolyásolása, átdolgozása, aminek azonban elengedhetetlen feltétele azok pontos feltérképezése és vizsgálata.

Megfelelő adherencia hiányában a cukorbeteg gyermekek és fiatalok súlyos szövődményekkel szembesülhetnek, amelyek jelentősen befolyásolhatják az élettartamot és az életminőséget, de olyan tényezőkre is hatással lehet, mint a családdinamika és az anyagi helyzet. Az l-es típusú diabetesszel diagnosztizált fiatalok mindöszsze 21\%-a képes az American Diabetes Association által kitűzött $\mathrm{HbA}_{\mathrm{lc}}$-szintet megtartani [2]. Mivel a glikémiás kontroll jellemzően serdülőkorban a legrosszabb, nagyon fontos kitüntetett figyelemmel kísérni annak fejlesztését a krónikus hyperglykaemiához társuló többszervi szövődmény csökkentésének érdekében (például vesebetegség, szembetegség, szív- és érrendszeri betegségek és neuropátia) [6]. A serdülőkor alapvetően kritikus periódus számos fiziológiai, hormonális és pszichoszociális változással, amely a betegség megjelenésében, de az azzal kapcsolatos adherenciában is jelentős hatású. A serdülőkorban bekövetkező hormonális változások inzulinrezisztenciát okozhatnak, számos más tényező pedig (pszichoszociális, kezeléssel és kommunikációval kapcsolatos faktorok) gyenge glikémiás kontrollhoz vezethet. Ugyanakkor a tünetek csökkenéséhez és a beteg javuló állapotához jelentősen hozzájárul a kezelési protokoll betartása, a folyamatos kapcsolattartás az orvosi teammel és a társas támasz lehetősége, mely tényezők az adherencia körébe tartoznak. A glikémiás kontroll és a kezelés betartása közötti összefüggés arra utal, hogy a glikémiás kontroll javítása érdekében a terápiás adherenciát javítani szükséges. Ezen tényezők adják a jelen kutatás relevanciáját, mivel az adherencia vizsgálatára alkalmazott eddigi kérdőívek és egyéb kutatási módszerek annak csak egy-egy spektrumát s nem a teljes adherenciát fedik le. Ennek a hiánynak a pótlására vizsgálatunk céljául egy komplex, adherenciát vizsgáló kérdőív kifejlesztését tüztük ki [7].

Áttekintve a szakirodalmat, 10 olyan releváns kérdőívet találtunk, amely a cukorbeteg gyermekek és serdülők diabeteshez, illetve az azzal való együttéléshez és életmódjukban hozott változásokhoz való viszonyulását - azaz valamilyen tartalom mentén az adherenciát - vizsgálta. Ezek a kérdőívek nagyon hosszúak voltak, és csak egyes területekre vonatkoztak. A kutatók szemléletmódja többnyire hasonló, de tartalmi vonatkozásaiban változó megközelítéseket írnak le, ezért a 10 kérdooív tételeit metaanalízissel tartalmi kategóriákba rendeztük, majd megvizsgáltuk azok megfelelő koherenciáját, az átfedő tartalmakat elhagytuk, illetve összevontuk, tartalmi kategória elvesztését így elkerültük. Az eddig használt kérdőívek tartalmi kategóriáinak rendezését követően a tartalmi kategóriák véglegesítését zsưriztetéssel végeztük.

\section{Módszer}

A jelen kutatás célja egy új, a diabetesadherenciával kapcsolatos attitüdök mérésére szolgáló kérdőív kialakítása, bemutatása, valamint eredményeinek szemléltetése 114 fó, l-es típusú cukorbetegséggel diagnosztizált gyermek és serdülő körében való tesztelés alapján. Így e vizsgálatban egy új, a diabetesspecifikus adherenciát és az azzal kapcsolatos attitüdöket párhuzamosan vizsgáló kérdőív bemutatására kerül sor. A Diabetes Adherencia Kérdőív rövidített változata olyan komplex eszköz, mely a diabetesszel kapcsolatos attitűdök és viselkedés valamennyi aspektusát méri az 58 állításra adott válasz segítségével. A kérdőív első változatának létrehozása tíz angol nyelvü kérdőív lefordításával, majd eredeti nyelvre történő viszszafordításával történt meg, amely ebben a formájában 167 állítást tartalmazott [8-17].

Az állításokat 10 szakember és egy 10 fös betegcsoport bevonásával zsúriztettük, amelynek eredményeként kilenc alskála került azonosításra, a pontos kategorizálás érdekében azonban a későbbiekben faktoranalízist végeztünk a hibaküszöb csökkentéséért. A 167 állítást tartalmazó kérdőívünket 20 fóvel előtesztelés alá vetettük. A kérdőív így is megbízhatónak mutatkozott (Cronbach- $\alpha=0,769)$, mivel a 0,6 feletti Cronbach- $\alpha$-értéket már elfogadhatónak tartjuk, s ennél a kérdőív megbízhatósága jóval magasabb.

Az így létrehozott kérdőív az elvégzett faktoranalízis alapján kilenc faktort, tehát kilenc alskálát tartalmazott, amelyek a következők: 1) a cukorbetegség kezelési-ellátási elóírások megértése, szervezése, a cukorbetegséggel kapcsolatos tennivalók (a kezelési protokoll) betartása, 
teljesítése; 2 ) a vércukorméréshez kapcsolódó érzelmi reakciók; 3 ) a szülői és családi támasz; 4) a kortárskapcsolatok; 5) a betegségtagadás (a cukorbetegség tagadása); 6) az adherencia pozitív következményei; 7) az adherencia negatív következményei, fájdalom, kellemetlenség, teher; 8) az orvosi teammel való kapcsolat; 9) a jövővel kapcsolatos aggodalom. A kérdőív állításait ötfokú Likert-skálán (1-5) kell értékelni.

A kérdőív kitöltése ugyanakkor nagyon hosszadalmasnak bizonyult, személyenként 30-50 percet vett igénybe, s a figyelmi korlátok, környezeti hatások és életkori sajátosságok (gyerek- és serdülőkor) okán fontolóra kellett venni egy rövidebb, ám tartalmilag szorosan illeszkedő kérdőív kialakítását. Ennek érdekében az állítások számát redukáltuk azok megbízhatósága, valamint faktorsúlyuk alapján. Az egyes skálákban a legkevésbé megbízható kijelentések kivételre kerültek. Így az eredetileg 167 állítást tartalmazó kérdőív rövidített változata 58 állítást tartalmaz. A kérdőív újratesztelésében (tesztreteszt) részt vevő gyermekek a Debreceni Egyetem Klinikai Központjának Gyermekgyógyászati Klinikáján állnak kezelés alatt l-es típusú cukorbetegséggel diagnosztizálva $(\mathrm{n}=114)$, a kutatásra pedig a Debreceni Egyetem Klinikai Központja Gyermekgyógyászati Klinikájának Gyermekgyógyászati és Pszichoszomatikus Osztályán került sor. A legfiatalabb páciens 9 éves, a legidősebb pedig 20 éves, a minta átlagéletkora 14,17 év $(s d=2,18)$. A minta $52,6 \%$-a fiú $(\mathrm{n}=60), 47,4 \%$-a pedig lány $(\mathrm{n}=$ 54). A fiatalok 67,5\%-a él intakt családban, 21,9\%-uk él csak az egyik szülőjével (és annak új párjával), s 8,8\%-uk él nevelőszülőknél. 16,7\%-uknak nincs testvére, míg 83,3\%-uknak van legalább egy testvére. A betegség kezdetének átlagos időpontja a 8,18 éves kor $(\mathrm{sd}=3,9)$, a vizsgálat időpontjáig a diagnózis óta eltelt idő átlaga 7,1 év $(\mathrm{sd}=3,8)$.

\section{Eredmények}

A statisztikai számítások során SPSS 22.0 for Windows statisztikai programot (Microsoft Corporation, Armonk, NY, Amerikai Egyesült Államok) alkalmaztunk, a megbízhatóságot Cronbach- $\alpha$ mutatóval, a kérdőív skáláit faktoranalízissel hoztuk létre. A további elemzésekhez kétmintás t-próbát alkalmaztunk két csoport összehasonlításakor s egyszempontos varianciaanalízist több csoport eredményeinek összevetése során. A jelen kutatásban a kérdőív megbízhatósága magasnak mondható, hiszen az újratesztelés után a Cronbach- $\alpha$ értéke 0,739 . Az egyes alskálák megbízhatóságát az 1. táblázat szemlélteti.

Faktoranalízissel megvizsgáltuk a kérdőívben mintázódó alskálákat, azt feltételezve, hogy az eredetileg meghatározott kilenc alskálát követő mintázat lesz tapasztalható. Ehhez 'maximum likelihood' (legnagyobb valószínûség) módszerrel Varimax rotálást alkalmaztunk, amely 71,4\%-ban magyarázza a változókat. A faktoranalízis eredményei alapján hasonló eloszlás volt kimutatható a kérdések csoportosulásának tekintetében, így az eredeti-
1. táblázat | Megbízhatóság a Diabetes Adherencia Kérdőív (DAK) rövidí tett változatának alskáláin (forrás: Diabetes Adherencia Felmérés [DAF] 2017; $\mathrm{n}=114$ )

\begin{tabular}{lc}
\hline Alskálák & Cronbach- $\alpha$ \\
\hline 1. Önmenedzselés (self-management) & 0,844 \\
$\begin{array}{l}\text { 2. Emocionális feedback (a vércukorméréssel } \\
\quad \text { kapcsolatos érzelmi reakciók) }\end{array}$ & 0,623 \\
3. Társas támasz (szüló és család) & 0,882 \\
4. Társas támasz (kortársak) & 0,674 \\
5. Betegségtagadás & 0,714 \\
6. Pozitív adherencia & 0,745 \\
7. Negatív adherencia & 0,839 \\
8. Társas támasz (orvosi team) & 0,673 \\
9. Jövókép & 0,841 \\
\hline
\end{tabular}

hez hasonlóan kilenc alskálát állapíthattunk meg (Melléklet).

Az új, rövidített komplex kérdőívet 114 beteg bevonásával teszteltük. A teljes kérdőív megbízhatósága igen magas (Cronbach- $\alpha=0,881$ ). A kérdőív kilenc skálát tartalmaz, amelyek a következők:

1. Önmenedzselés (self-management): a cukorbetegség-kezelési előírások megértése, szervezése, a cukorbetegséggel kapcsolatos tennivalók (a kezelési protokoll) betartása, teljesítése, a kezelési utasítások (táplálkozás, vércukorszintmérés, inzulininjekció) percepciója, figyelembevétele, azok körültekintő betartása, tudatos magatartás (50 pont).

2. Emocionális feedback (a vércukorméréssel kapcsolatos érzelmi reakciók): pozitív és negatív emóciók a vércukorszinttel és annak mérésével kapcsolatban, annak közlése a környezettel, a cukorbetegség általi fenyegetettség fiziológiai és emocionális megjelenése (30 pont).

3. Társas támasz (szülő és család): a család és családtagok szerepe a cukorbetegségben és az azzal való megküzdésben, a családból érkező pozitív és negatív feedback és azok hatása ( 55 pont).

4. Társas támasz (kortársak): a barátok által nyújtott társas támasz megnyilvánulási formái és szerepe a betegséggel való megküzdésben, izoláció vagy integráció jelenléte a cukorbeteg gyermek életében ( 25 pont).

5. Betegségtagadás: a cukorbetegség tényének tudatos és tudattalan figyelmen kívül hagyása, tagadása, a tünetek és a kezelési rend izolálása, a tünetektől való félelem hiánya ( 15 pont).

6. Pozitív adherencia: az adherencia pozitív következményei, a kezelési előírások és a sport pozitív hatásai a fiziológiai és emocionális jóllétre (10 pont).

7. Negatív adherencia: betegségteher, az adherencia negatív következményei, fájdalom, kellemetlenség, teher: a betegség és következményeinek negatív hatásai a mindennapi életre, a kapcsolatokra, a szabadidős és iskolai tevékenységekre ( 45 pont).

8. Társas támasz (orvosi team): a cukorbeteg gyermek kapcsolata és viszonyulása az orvos(ok)hoz, az orvosok magatartásának percepciója (25 pont). 
Skálaértékek a Diabetes Adherencia Kérdőív (DAK) rövidítet változatának alskáláin nemi bontásban (forrás: Diabetes Ad herencia Felmérés [DAF] 2017; n = 114)

\begin{tabular}{lrr|rr|l}
\hline \multirow{2}{*}{ Nem } & \multicolumn{2}{c|}{ Fiú } & \multicolumn{2}{c}{ Lány } & \\
& \multicolumn{2}{c}{$(\mathrm{n}=60)$} & \multicolumn{2}{c}{$(\mathrm{n}=54)$} & \\
\cline { 2 - 6 } & Átlag & Szórás & Átlag & Szórás & Szign. \\
\hline 1. alskála & 40,0 & 10,0 & 38,0 & 11,8 & 0,333 \\
2. alskála & 15,5 & 3,6 & 15,4 & 4,9 & 0,978 \\
3. alskála & 47,2 & 13,9 & 47,0 & 15,2 & 0,956 \\
4. alskála & 18,3 & 3,1 & 18,4 & 5,1 & 0,925 \\
5. alskála & 5,6 & 2,1 & 5,0 & 2,0 & 0,168 \\
6. alskála & 7,9 & 2,0 & 7,8 & 2,7 & 0,783 \\
7. alskála & 16,2 & 7,3 & 13,8 & 6,0 & 0,064 \\
8. alskála & 21,9 & 4,2 & 21,6 & 5,9 & 0,805 \\
9. alskála & 11,8 & 5,8 & 8,8 & 4,4 & 0,002 \\
\hline Összesen & 184,3 & 34,5 & 175,9 & 48,1 & 0,284 \\
\hline
\end{tabular}

9. Jövőkép: a jövővel kapcsolatos aggodalom, a cukorbetegség hosszú távú negatív hatásaitól való félelem a házasság, gyermekvállalás, továbbtanulás és munkavállalás, egészség és annak hiánya vonatkozásában (30 pont).

Az adatok és skálaértékek szemléltetésének érdekében korcsoportonkénti bontásban szemléltetjük a DAK gyermekváltozatán elért értékeket. Ehhez a kilenc alskála értékeinek külön-külön történő ismertetése mellett a teljes kérdőíven elért átlagokat is tartalmazza a 2., 3. és 4. táblázat. A teljes mintaátlag a 114 bevont vizsgálati személy adatai alapján 179,6 pont. A fiúk teljes adherenciaátlaga 184,3 pont, míg a lányoké 175,9 pont, ami arra utal, hogy a fiúk terápiás adherenciája magasabb, jóllehet a különbség nem szignifikáns (2. táblázat). Az alskálák tekintetében csak a Jövőkép alskála esetében áll fenn jelentôs különbség a nemek közt, amely a fiúk pozitívabb jövőképét mutatja. A többi alskála esetében nem jelentős a csoportok közti különbség.
4. táblázat $\mid$ Skálaértékek a Diabetes Adherencia Kérdőív (DAK) rövidítet változatának alskáláin családszerkezet szerinti bontásban (forrás: Diabetes Adherencia Felmérés [DAF] 2017; n = 112)

\begin{tabular}{lrr|rr|rr|r}
\hline $\begin{array}{l}\text { Család- } \\
\text { szerkezet }\end{array}$ & \multicolumn{2}{c|}{$\begin{array}{c}\text { Intakt } \\
(\mathrm{n}=77)\end{array}$} & \multicolumn{2}{c|}{$\begin{array}{c}\text { Nonintakt } \\
(\mathrm{n}=25)\end{array}$} & \multicolumn{2}{c}{$\begin{array}{c}\text { Nevelőszülők } \\
(\mathrm{n}=10)\end{array}$} & \\
\hline & Átlag & Szórás & Átlag & Szórás & Átlag & Szórás & Szign. \\
\hline 1. alskála & 40,1 & 7,1 & 39,3 & 12,1 & 33,7 & 8,7 & 0,267 \\
2. alskála & 16,2 & 2,5 & 15,5 & 4,6 & 13,5 & 5,5 & 0,235 \\
3. alskála & 47,0 & 13,1 & 48,0 & 14,9 & 38,9 & 13,9 & 0,174 \\
4. alskála & 19,1 & 3,1 & 17,9 & 4,7 & 19,6 & 1,6 & 0,292 \\
5. alskála & 5,2 & 1,8 & 5,2 & 2,2 & 6,3 & 1,4 & 0,285 \\
6. alskála & 8,1 & 1,5 & 7,9 & 2,5 & 6,3 & 2,5 & 0,098 \\
7. alskála & 16,8 & 6,8 & 14,5 & 6,8 & 15,3 & 6,6 & 0,315 \\
8. alskála & 22,4 & 3,1 & 21,6 & 5,7 & 21,0 & 4,3 & 0,703 \\
9. alskála & 11,4 & 5,6 & 10,0 & 5,4 & 10,1 & 5,4 & 0,545 \\
\hline Összesen & 186,4 & 21,8 & 180,0 & 47,1 & 164,7 & 35,0 & 0,388 \\
\hline
\end{tabular}

A minta az életkor alapján négy jól elkülöníthető csoportra bontható: a 9-12 évesek $(\mathrm{n}=34)$, a 13-14 évesek $(\mathrm{n}=26)$, a 15-16 évesek $(\mathrm{n}=32)$, valamint a $17-20$ évesek ( $\mathrm{n}=21$ ) csoportjára. Megvizsgáltuk, milyen különbségek állnak fenn életkor szerint az adherenciában, ennek eredményeit a 3. táblázat szemlélteti. Az eredmények alapján a 13-14 évesek körében a legmagasabb az adherencia mértéke, míg a 17-20 évesek körében a legalacsonyabb a szintje. A csoportok közötti különbség azonban nem szignifikáns, sem a teljes adherencia, sem annak alskálái esetében.

Végül a családszerkezet alapján fennálló adherenciakülönbségeket vizsgáltuk meg (4. táblázat). A legmagasabb adherenciával az intakt családban élő fiatalok jellemezhetők, míg a legalacsonyabb adherencia a nevelőszülőkkel élő gyerekek közt mutatkozott. A csoportok közötti különbség azonban nem szignifikáns.

3. táblázat Skálaértékek a Diabetes Adherencia Kérdőív (DAK) rövidített változatának alskáláin életkori bontásban (forrás: Diabetes Adherencia Felmérés [DAF] 2017; $\mathrm{n}=114$ )

\begin{tabular}{|c|c|c|c|c|c|c|c|c|c|}
\hline \multirow[t]{2}{*}{ Korcsoport } & \multicolumn{2}{|c|}{$\begin{array}{l}9-12 \text { év } \\
(\mathrm{n}=34)\end{array}$} & \multicolumn{2}{|c|}{$\begin{array}{l}13-14 \text { év } \\
(\mathrm{n}=26)\end{array}$} & \multicolumn{2}{|c|}{$\begin{array}{l}15-16 \text { év } \\
(\mathrm{n}=32)\end{array}$} & \multicolumn{2}{|c|}{$\begin{array}{c}17-20 \\
(\mathrm{n}=21)\end{array}$} & \multirow[b]{2}{*}{ Szign. } \\
\hline & Átlag & Szórás & Átlag & Szórás & Átlag & Szórás & Átlag & Szórás & \\
\hline 1. alskála & 38,7 & 14,2 & 39,7 & 7,1 & 41,1 & 9,1 & 35,2 & 11,0 & 0,274 \\
\hline 2. alskála & 15,0 & 5,8 & 15,9 & 1,9 & 15,4 & 3,9 & 15,5 & 4,1 & 0,887 \\
\hline 3. alskála & 49,1 & 17,8 & 48,6 & 8,0 & 46,4 & 14,3 & 42,0 & 14,5 & 0,311 \\
\hline 4. alskála & 17,9 & 4,9 & 18,7 & 2,9 & 18,4 & 4,2 & 18,6 & 4,5 & 0,880 \\
\hline 5. alskála & 5,1 & 2,2 & 5,3 & 1,9 & 5,6 & 2,2 & 5,3 & 1,8 & 0,831 \\
\hline 6. alskála & 7,6 & 3,1 & 8,4 & 1,5 & 7,9 & 2,1 & 7,3 & 2,1 & 0,409 \\
\hline 7. alskála & 15,0 & 8,7 & 15,8 & 6,0 & 14,5 & 5,8 & 15,2 & 6,0 & 0,903 \\
\hline 8. alskála & 21,2 & 6,2 & 22,1 & 2,9 & 22,5 & 5,0 & 21,0 & 5,4 & 0,623 \\
\hline 9. alskála & 9,5 & 7,0 & 10,2 & 3,7 & 10,8 & 5,0 & 11,6 & 5,0 & 0,566 \\
\hline Összesen & 179,1 & 57,2 & 184,8 & 14,7 & 182,7 & 37,0 & 171,8 & 42,5 & 0,732 \\
\hline
\end{tabular}




\section{Megbeszélés}

Tanulmányunk fókuszában az l-es típusú cukorbetegség adherenciájával kapcsolatos attitűdök és viselkedéselemek vizsgálata állt. A tanulmány célja egyrészt egy új, komplex, de rövidebb, az adherencia és az azzal kapcsolatos attitűdök vizsgálatára szolgáló mérőeszköz kialakítása és bemutatása, valamint hatékonyságának szemléltetése. Az eredetileg 167 állítást tartalmazó 10 angol nyelvű nemzetközi kérdőív lefordításának eredményeként létrehozott kérdőívünk a 20 fôs előtesztelés alkalmával megbízhatónak bizonyult ugyan, ám terjedelmi okok miatt nehézségekbe ütközött a kérdőívek felvétele. Így a megbízhatósági mutatók és faktoranalízis alapján redukált, 58 állítást tartalmazó új, rövidített kérdőívünknek a 114 fós mintánkon elvégzett tesztelése megbízhatónak bizonyult, s kilenc faktor rajzolódott ki, így a létrehozott kérdőív kilenc alskálát tartalmaz. Ezek a következőek: önmenedzselés (self-management), emocionális feedback (a vércukorméréssel kapcsolatos érzelmi reakciók), társas támasz (szülō és család), társas támasz (kortársak), betegségtagadás, pozitiv adherencia, negatí adberencia, társas támasz (orvosi team), valamint jövőkép. A kérdőív előnye, hogy rövid idő alatt kitölthető, s megbízhatóan képes mérni a diabetesadherencia esetében jelentős területeket akár már prepubertáskorban, szemben a jelenleg rendelkezésre álló kérdőívekkel, amelyek részben hosszabb időtartamot igényelnek, részben pedig csak részterületeket képesek lefedni, ami a kérdőív kialakításának kifejezett relevanciáját szemlélteti. Könnyü értelmezhetőségének okán így a kérdőív jól alkalmazható már prepubertás- és serdülőmintán, ugyanakkor felnőtt populációra is adaptálható. A jelen kutatás tárgyát nem képezte a demográfiai háttérváltozók, valamint az egyéb pszichológiai faktorok bevonása és hatásuk vizsgálata, amelyek azonban további izgalmas és értékes kutatási kérdéseket és eredményeket vethetnek fel, így ezek későbbi kutatásaink részét fogják képezni. További kutatási céljaink között szerepel ennek megfelelően egy szülői és szakorvosi együttmúködési kérdőív létrehozása is. Fontos lenne az új adherencia-kérdőív használata minden diabeteses gyermeknél, hiszen jelentős és objektív visszajelzéseket kaphatunk. Így az intervenciókat, a pszichés szupportív támogatást korábban meg tudjuk kezdeni egyénileg és a család részéről is. Hosszú távon a kérdőív angol nyelvre történő fordításával a kérdőív terjesztése és szélesebb körü alkalmazása is elérhetővé válik, mivel jelenleg az angol nyelvü irodalomban sem találkozhatunk hasonló, rövid, ugyanakkor komplex adherencia-kérdőívvel. Ezt követően a kérdőívet egyéb krónikus betegségekre (például Chron-betegség, colitis ulcerosa, asztma) is adaptálni lehet, s ezáltal a különböző krónikus betegségekkel rendelkező betegcsoportok terápiás adherenciája is összehasonlíthatóvá válhat.

Melléklet | A Diabetes Adherencia Kérdő́iv gyermekváltozata (DAK-GY)

A továbbiakban a cukorbetegséggel és annak kezelésével kapcsolatos állításokat olvashatsz. Kérlek, állapítsd meg, mennyire jellemzőek rád ezek az állítások! Az l-es az egyáltalán nem, míg az 5-ös a teljes mértékben jellemző.

\begin{tabular}{|c|c|c|c|c|c|}
\hline \multirow[b]{2}{*}{ 1. Kezelésem kellemetlenséget okoz. } & \multicolumn{2}{|c|}{$\begin{array}{l}\text { Egyáltalán } \\
\text { nem }\end{array}$} & \multicolumn{3}{|c|}{$\begin{array}{l}\text { Teljes } \\
\text { mértékben }\end{array}$} \\
\hline & 1 & 2 & 3 & 4 & 5 \\
\hline 2. Kezelésem sok időt és munkát igényel. & 1 & 2 & 3 & 4 & 5 \\
\hline 3. Semmi rossz nem történhet velem, ha nem tartom be a kezelési rendet. & 1 & 2 & 3 & 4 & 5 \\
\hline 4. A barátokkal való kapcsolat fontosabb, mint cukorbetegségem kezelése. & 1 & 2 & 3 & 4 & 5 \\
\hline 5. Próbálom elfelejteni cukorbetegségemet. & 1 & 2 & 3 & 4 & 5 \\
\hline 6. Cukorbetegségem miatt megkülönböztetnek baráti társaságomban. & 1 & 2 & 3 & 4 & 5 \\
\hline 7. Megbízom az orvosokban. & 1 & 2 & 3 & 4 & 5 \\
\hline 8. Az orvosok túlságosan elfoglaltak ahhoz, hogy beszéljenek velem cukorbetegségemről. & 1 & 2 & 3 & 4 & 5 \\
\hline 9. Az orvosok megértik, hogy cukorbetegségem mennyire akadályoz a számomra fontos dolgokban. & 1 & 2 & 3 & 4 & 5 \\
\hline 10. Az orvosok barátságosak és könnyen tudnak velem beszélgetni. & 1 & 2 & 3 & 4 & 5 \\
\hline 11. Megbízom a nővérekben. & 1 & 2 & 3 & 4 & 5 \\
\hline 12. Betartom a kezelési előírásokat. & 1 & 2 & 3 & 4 & 5 \\
\hline 13. Családom biztat diétám betartására. & 1 & 2 & 3 & 4 & 5 \\
\hline 14. Családom emlékeztet diétám betartására. & 1 & 2 & 3 & 4 & 5 \\
\hline 15. Családtagjaim kontrollálják megfelelő ételfogyasztásomat. & 1 & 2 & 3 & 4 & 5 \\
\hline 16. Családtagjaim készítik el a diétás ételeket számomra. & 1 & 2 & 3 & 4 & 5 \\
\hline 17. Családtagjaim megdicsérnek, ha megfelelően étkezem, betartom a diétámat. & 1 & 2 & 3 & 4 & 5 \\
\hline 18. Családom figyelmeztet, ha nem megfelelő ételt eszem. & 1 & 2 & 3 & 4 & 5 \\
\hline 19. Eleget mozgok, sportolok. & 1 & 2 & 3 & 4 & 5 \\
\hline 20. Családom megdicsér a fizikai aktivitásért, sportért. & 1 & 2 & 3 & 4 & 5 \\
\hline
\end{tabular}




\begin{tabular}{|c|c|c|c|c|}
\hline \multirow[b]{2}{*}{ Családtagjaim sporttevékenységek végzésére bátorítanak. } & $\begin{array}{l}\text { Egyáltalán } \\
\text { nem }\end{array}$ & \multicolumn{3}{|c|}{$\begin{array}{l}\text { Teljes } \\
\text { mértékben }\end{array}$} \\
\hline & 2 & 3 & 4 & 5 \\
\hline 22. Ha lehet, elkerülöm, hogy társaim tudjanak cukorbetegségemről. & 2 & 3 & 4 & 5 \\
\hline 23. Zavar, ha barátaim cukorbetegségemről kérdeznek. & 2 & 3 & 4 & 5 \\
\hline 24. Barátaim többsége nem cukorbeteg, ezért másnak érzem magam. & 2 & 3 & 4 & 5 \\
\hline 25. Jobban szeretem, ha családtagjaim közlik helyettem környezetemmel cukorbetegségemet. & 2 & 3 & 4 & 5 \\
\hline 26. Jobban szeretem, ha én közlöm környezetemmel cukorbetegségemet. & 2 & 3 & 4 & 5 \\
\hline 27. Megfelelő ételmennyiséget eszek. & 2 & 3 & 4 & 5 \\
\hline 28. Étkezéseimet (reggeli/tízórai/ebéd stb.) megfelelő időben végzem. & 2 & 3 & 4 & 5 \\
\hline 29. Megfelelő inzulinmennyiséget adok be magamnak. & 2 & 3 & 4 & 5 \\
\hline 30. Megfelelő időben adom be magamnak az inzulint. & 2 & 3 & 4 & 5 \\
\hline 31. Vércukormérésem eredményét figyelembe véve adom be magamnak az inzulint. & 1 & 3 & 4 & 5 \\
\hline 32. Búntudatot vált ki, ha magas a vércukorszintem. & 1 & 3 & 4 & 5 \\
\hline 33. Félelmet vált ki, ha alacsony a vércukorszintem. & 2 & 3 & 4 & 5 \\
\hline 34. Minden körülmények között megmérem a vércukromat. & 2 & 3 & 4 & 5 \\
\hline 35. Rendszeresen rögzítem vércukorszintem mérésének eredményeit. & 2 & 3 & 4 & 5 \\
\hline 36. Mindent megteszek, hogy kordában tartsam cukorbetegségemet. & 2 & 3 & 4 & 5 \\
\hline 37. Cukorbetegségem korlátozza baráti kapcsolataimat. & 2 & 3 & 4 & 5 \\
\hline 38. Cukorbetegségem nagyban korlátozza életvitelemet. & 2 & 3 & 4 & 5 \\
\hline 39. Cukorbetegségem megfelelő kezelése sok időt vesz igénybe. & 2 & 3 & 4 & 5 \\
\hline 40. Családom örül, ha megfelelően kezelem magam. & 2 & 3 & 4 & 5 \\
\hline 41. Minél jobban betartom kezelési elóírásaimat, annál jobban érzem magam. & 2 & 3 & 4 & 5 \\
\hline 42. Diétám jelentősen korlátoz életvezetésemben. & 2 & 3 & 4 & 5 \\
\hline 43. Cukorbetegségem korlátoz a mozgásban, sportolásban. & 2 & 3 & 4 & 5 \\
\hline 44. Cukorbetegségem korlátozza szabadidős tevékenységeimet. & 2 & 3 & 4 & 5 \\
\hline 45. Cukorbetegségem korlátozza iskolai tevékenységeimet. & 2 & 3 & 4 & 5 \\
\hline 46. Aggódom, hogy cukorbetegségem miatt megházasodom-e. & 2 & 3 & 4 & 5 \\
\hline 47. Aggódom, hogy lehet-e majd gyermekem a cukorbetegségem miatt. & 2 & 3 & 4 & 5 \\
\hline 48. Aggódom, hogy nehezebb lesz majd állást találnom cukorbetegségem miatt. & 2 & 3 & 4 & 5 \\
\hline 49. Aggódom, hogy nem tudom majd befejezni iskolai tanulmányaimat cukorbetegségem miatt. & 2 & 3 & 4 & 5 \\
\hline 50. Aggódom, hogy cukorbetegségem testi megjelenésemet is befolyásolja. & 2 & 3 & 4 & 5 \\
\hline 51. Aggódom, hogy egészségügyi komplikációim adódnak cukorbetegségem miatt. & 1 & 3 & 4 & 5 \\
\hline 52. Cukorbetegségemmel kapcsolatos félelmeimet kordában tudom tartani. & 1 & 3 & 4 & 5 \\
\hline 53. Egy étkezés alkalmával diétámnak megfelelő ételmennyiséget eszek meg. & 1 & 3 & 4 & 5 \\
\hline 54. Családom megdicsér, ha betartom a kezelési előírásokat. & 2 & 3 & 4 & 5 \\
\hline 55. Családtagjaim segítenek a kezelés változtatásában vércukormérésem alapján. & 1 & 3 & 4 & 5 \\
\hline 56. Magas vércukorszintem miatt megijedek. & 1 & 3 & 4 & 5 \\
\hline 57. Alacsony vércukorszintem miatt megijedek. & 1 & 3 & 4 & 5 \\
\hline 58. Időnként megfeledkezem cukorbetegségem kezeléséről. & 1 & 3 & 4 & 5 \\
\hline
\end{tabular}

Értékelési útmutató:

1 Önmenedzselés (self-management): 12., 27., 28., 29., 30., 31., 34., 35., 36., 53.

2. Emocionális feedback (a vércukorméréssel kapcsolatos érzelmi reakciók): 25., 26., 32., 33., 52 ., 56.

3. Társas támasz (szülő és család): 13., 14., 15., 16., 17., 18., 20., 21., 40., 54., 55.

4. Társas támasz (kortársak): 4., 6., 22., 23., 24.

5. Betegségtagadás: 3., 5., 58 .

6. Pozitív adherencia: $19 ., 41$.

7. Negatív adherencia: 1., 2., 37., 38., 39., 42., 43., 44., 45.

8. Társas támasz (orvosi team): 7., 8., 9., 10., 11.

9. Jövőkép: 46., 47., 48., 49., 50., 51.

Fordított itemek: $4,6,8,23,24,32,33,56$. 
Anyagi támogatás: A szerzők anyagi támogatásban nem részesültek.

Szerzői munkamegosztás: M. B.: A kutatási módszertan kidolgozása, a vizsgálat lefolytatása, szakirodalom-kutatás, statisztikai elemzések, a kézirat kialakítása és szövegezése. N. B. E.: A kutatási módszertan kidolgozása és szupervíziója, szakirodalmi kutatás, a statisztikai adatok értelmezése, a kézirat kialakítása. K. K. E.: Szakirodalom-kutatás, statisztikai elemzések, a szempontrendszerek megtervezése. A cikk végleges változatát valamennyi szerző elolvasta és jóváhagyta.

Érdekeltségek: A szerzőknek nincsenek érdekeltségeik.

\section{Irodalom}

[1] Petitti DB, Klingensmith GJ, Bell RA, et al., for the SEARCH for Diabetes in Youth Study Group. Glycemic control in youth with diabetes: the SEARCH for Diabetes in Youth Study. J Pediatr. 2009; 155: 668-672.e3.

[2] Wood JR, Miller KM, Maahs DM, et al., TID Exchange Clinic Network. Most youth with type 1 diabetes in the TID Exchange Clinic Registry do not meet American Diabetes Association or International Society for Pediatric and Adolescent Diabetes Clinical Guidelines. Diabetes Care 2013; 36: 2035-2037.

[3] Ellis EN. Diabetes mellitus and the kidney in adolescents. Adolesc Med Clin. 2005; 16: 173-184.

[4] Leelarathna L, Guzder R, Muralidhara K, et al. Diabetes: glycaemic control in type 1. BMJ Clin Evid. 2011; 2011: 0607.

[5] World Health Organization, Chronic Respiratory Diseases and Arthritis Team. Screening for type 2 diabetes report of a World Health Organization and International Diabetes Federation meeting. Department of Noncommunicable Disease Management, Geneva, 2003.

[6] Hood KK, Peterson CM, Rohan JM, et al. Association between adherence and glycemic control in pediatric type 1 diabetes: a meta-analysis. Pediatrics 2009; 124: el171-el179.

[7] Datye KA, Moore DJ, Russell WE, et al. A review of adolescent adherence in type 1 diabetes and the untapped potential of diabetes providers to improve outcomes. Curr Diab Rep. 2015; 15 . 51.
[8] Anderson BJ, Auslander WF, Jung KC, et al. Assessing family sharing of diabetes responsibilities. J Pediatr Psychol. 1990; 15: $477-492$.

[9] Schafer LC, McCaul KD, Glasgow RE. Supportive and nonsupportive family behaviors: relationships to adherence and metabolic control in persons with type 1 diabetes. Diabetes Care 1986; 9: 179-185.

[10] Hood KK, Butler DA, Anderson BJ, et al. Updated and revised diabetes family conflict scale. Diabetes Care 2007; 30: 17641769.

[11] La Greca AM, Bearman, KJ. The diabetes social support questionnaire - family version: evaluating adolescents' diabetes-specific support from family members. J Pediatr Psychol. 2002; 27: 665-676.

[12] Hood KK, Butler DA, Volkening LK, et al. The Blood Glucose Monitoring Communication Questionnaire. An instrument to measure affect specific to blood glucose monitoring. Diabetes Care 2004; 27: 2610-2615.

[13] La Greca AM, Swales T, Klemp S, et al. Self care behaviors among adolescents with diabetes. Ninth Annual Sessions of the Society of Behavioral Medicine. Society of Behavioural Medicine, Baltimore, MD, 1988.

[14] Skinner TC, Hoey H, McGee HM, et al. A short form of the Diabetes Quality of Life for Youth questionnaire: exploratory and confirmatory analysis in a sample of 2,077 young people with type 1 diabetes mellitus. Diabetologia 2006; 49: 621-628.

[15] Iannoti RJ, Schneider S, Nansel TR, et al. Self-efficacy, outcome expectations, and diabetes self-management in adolescents with type 1 diabetes. J Dev Behav Pediatr. 2006; 27: 98-105.

[16] Jacobson AM, Hauser ST, Lavori P, et al. Adherence among children and adolescents with insulin-dependent diabetes mellitus over a four-year longitudinal follow-up. I. The influence of patient coping and adjustment. J Pediatr Psychol. 1990; 15: 511526.

[17] Cox ED, Fritz KA, Hansen KW, et al. Development and validation of PRISM: a survey tool to identify diabetes self-management barriers. Diabetes Res Clin Pract. 2014; 104: 126-135.

(Kovács Karolina Eszter dr., Debrecen, Egyetem tér 1., 4032 e-mail: karolina92.kovacs@gmail.com)

\section{"Fundamentum est omnium virtutum pietas in parentes." (Cicero) (Minden erény alapja a szülők iránti tisztelet.)}

A cikk a Creative Commons Attribution 4.0 International License (https://creativecommons.org/licenses/by/4.0/) feltételei szerint publikált Open Access közlemény, melynek szellemében a cikk bármilyen médiumban szabadon felhasználható, megosztható és újraközölhető, feltéve, hogy az eredeti szerző és a közlés helye, illetve a CC License linkje és az esetlegesen végrehajtott módosítások feltüntetésre kerülnek. (SID_1) 